\title{
Regulating telomere length from the inside out: the replication fork model
}

\author{
Carol W. Greider \\ Department of Molecular Biology and Genetics, Johns Hopkins University School of Medicine, Baltimore, Maryland 21205, USA; \\ Department of Biology, Johns Hopkins University, Baltimore, Maryland 21218, USA
}

Telomere length is regulated around an equilibrium set point. Telomeres shorten during replication and are lengthened by telomerase. Disruption of the length equilibrium leads to disease; thus, it is important to understand the mechanisms that regulate length at the molecular level. The prevailing protein-counting model for regulating telomerase access to elongate the telomere does not explain accumulating evidence of a role of DNA replication in telomere length regulation. Here I present an alternative model: the replication fork model that can explain how passage of a replication fork and regulation of origin firing affect telomere length.

Telomere length homeostasis is essential for cell survival. Short telomeres trigger DNA damage, induce cellular senescence and apoptosis, and cause short telomere syndromes and associated age-related disease (Armanios 2009|. Cancer cells, on the other hand, maintain or elongate telomeres and escape senescence to allow immortal growth (Greider 1999). Telomeres naturally shorten during DNA replication, which is counterbalanced by de novo addition of telomere sequences by telomerase (Greider and Blackburn 1985). Most of the telomere is replicated by conventional replication machinery (Wellinger and Zakian 2012); however, at each cell cycle, telomerase elongates a few telomeres by addition of a few repeats (Teixeira et al. 2004). The central question is: What determines whether a telomere will be elongated and how does this establish length homeostasis? Here I present a model for how the stochastic elongation of telomeres at each cell cycle can be explained by coupling between DNA replication and telomere length maintenance.

\section{Telomere-binding proteins regulate telomere length}

Telomeres are made up of simple G-rich DNA sequence repeats that are packaged into chromatin (Tommerup et al. 1994) and bound by telomere-specific binding pro-

[Keywords: DNA replication; telomerase; telomere]

Corresponding author: cgreider@jhmi.edu

Article is online at http://www.genesdev.org/cgi/doi/10.1101/gad.280578. 116. Freely available online through the Genes $\Perp$ Development Open Access option. teins. In mammalian cells, the shelterin complex consists of TRF1 and TRF2, which bind along the double-stranded telomere sequence and recruit associated proteins TIN2, TPP1, POT1, and RAP1 (Palm and de Lange 2008). POT1 binds tightly to the single-stranded G-rich telomere DNA sequence. Telomeres in Saccharomyces cerevisiae were initially reported to be nonnucleosomal (Wright et al. 1992); however, recent data suggest nucleosomal packaging in yeast as well as mammalian cells (Rossetti et al. 2001; Pisano et al. 2008). In S. cerevisiae, the Rap1 protein binds to the double-stranded telomere repeats and either Rif1 and Rif2 or Sir3 and Sir4 bind to the C-terminal domain of Rap1 (Shore and Bianchi 2009). The singlestranded G-rich telomeric DNA is bound by Cdc13 (Lin and Zakian 1996; Nugent et al. 1996) and the associated Stn1 and Ten1 proteins (Grandin et al. 1997, 2001). The double-stranded and single-stranded telomere-specific binding proteins are essential for both protecting the chromosome end and regulating telomerase access to the telomere (Palm and de Lange 2008; Wellinger and Zakian 2012). How they carry out these functions is critical to understanding length regulation.

\section{Protein-counting model}

Several experimental findings helped establish the "protein-counting" model for telomere length regulation (Marcand et al. 1997). First, in S. cerevisiae, both C-terminal mutations in RAP1 (Sussel and Shore 1991) and deletion of the genes encoding two Rapl-interacting proteins, RIF1 and RIF2, cause excessive telomere elongation (Hardy et al. 1992; Wotton and Shore 1997), implying that these proteins normally block telomere elongation. Second, addition of extra artificial RAP1-binding sites shortens telomeres (Marcand et al. 1997). Third, short telomeres are more likely to be elongated by telomerase than long telomeres (Marcand et al. 1999; Teixeira et al. 2004). The "protein-counting" model for telomere length regulation (Fig. 1A) was first described to explain length regulation in yeast (Marcand et al. 1997) and was later adopted to explain mammalian telomere length

(C) 2016 Greider This article, published in Genes \& Development, is available under a Creative Commons License (Attribution 4.0 International), as described at http://creativecommons.org/licenses/by/4.0/. 
A
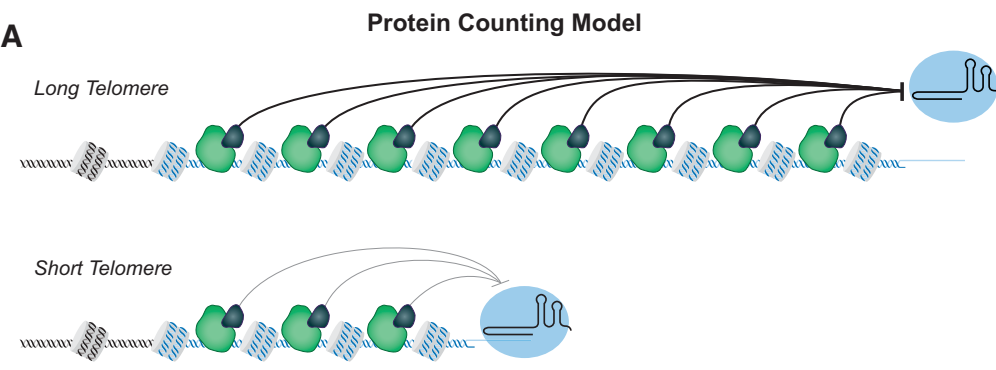

B

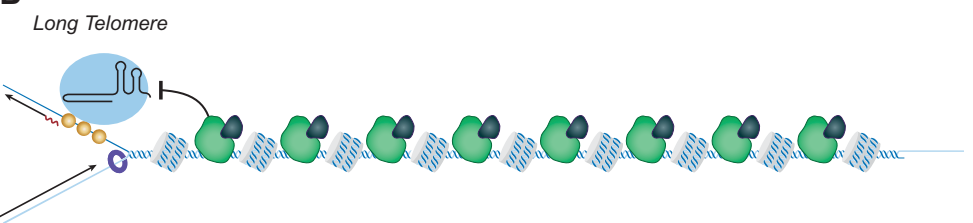

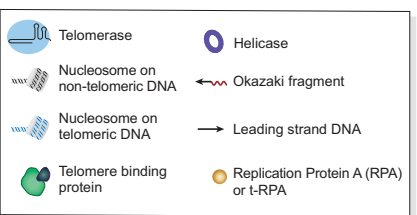

Figure 1. Old and new models for regulating elongation of telomeres by telomerase. (A) Protein-counting model: Telomeric DNA (blue helix) is shown packaged as nucleosomes and bound by interspersed telomere-specific proteins (green). The telomere proteins act from a distance to block telomerase (light blue) access to the end of the chromosome. (Top) The long telomere has greater repressive effects (black bar) on telomerase than the short telomere. $(B)$ Replication fork model: Telomerase is shown traveling with the lagging strand machinery. The RPA or t-RPA is shown in gold, and the helicase is shown as a purple ring. The fork replicates through nucleosomes and bound telomere proteins, either of which can cause dissociation of telomerase from the fork (curved blocking bar). Telomerase must remain bound to the fork until it reaches the extreme terminus for the telomere to be extended. regulation, since knockdown of the telomere-binding proteins TRF1, TRF2, POT1, and TIN2 also caused excessive telomere elongation (van Steensel and de Lange 1997; Loayza and de Lange 2003; Ye and de Lange 2004; Takai et al. 2010). The evolutionary conservation of negative telomere length regulation by telomere-binding proteins helped solidify the protein-counting model (Smogorzewska et al. 2000).

At its core, the protein-counting model states that there is an additive negative effect of telomere-bound proteins on telomerase access to the telomere. That is, long telomeres have a stronger repressive effect that keeps telomerase off the $3^{\prime}$ end of the telomere, while short telomeres have a weaker repressive effect and so telomerase can elongate them (Fig. 1A). Although this model explains the negative inhibitory role of telomere-binding proteins, it is unclear from a biophysical standpoint how an additive negative effect might be integrated and/or propagated along many kilobases of telomere sequence. Several modifications to this model have been proposed that involve looping of the telomere DNA. Grunstein (1997) proposed that long-distance interactions of telomere-bound proteins and subtelomeric nucleosomes sequester the telomere terminus. de Lange and colleagues /Griffith et al. 1999) proposed that $t$ loops in which the $3^{\prime}$ telomere end is base-paired with internal telomere repeats can regulate access of telomerase to the telomere. Finally, Lingner and colleagues (Teixeira et al. 2004) proposed a probabilistic model in which long telomeres are in a nonextendable state that can switch to an extendable state, and short telomeres have a higher probability of switching. While these models propose ways to potentially block telomeres from elongation, the mechanisms by which looping or "transitions in state" establish the exquisite normal distribution of telomere lengths are not clear.

The protein-counting model might suggest that telomere-binding proteins evolved primarily to regulate telomere length; however, even in the absence of telomerase, telomere-binding proteins regulate cell viability (Hockemeyer et al. 2008; Chang and Rothstein 2011; Ballew and Lundblad 2013). Finally, the protein-counting model does not explain a number of new experimental findings, as discussed below, suggesting that alternative models should be considered.

\section{A replication fork model for telomere length regulation}

An alternative model for telomere length regulation better accounts for new (and old) research linking DNA replication and telomere elongation. This "replication fork" model accounts for both negative regulation of telomere elongation and preferential elongation of short telomeres. In this model, telomerase travels with the replication fork and must be deposited at the end of the telomere for that telomere to be elongated (Fig. 1B). Telomere-binding proteins (and perhaps nucleosomes) exert a negative effect by increasing the probability that telomerase will dissociate from the traveling replication fork. Therefore, the longer the telomere, the lower the probability of telomerase reaching the end, where it can preform its catalytic 
function. On a longer telomere, the cumulative small probabilities of telomerase dissociation make it less likely that telomerase will arrive at the terminus. This model fits the long-established evidence that short telomeres are preferentially elongated and that telomere elongation is stochastic; only a few telomeres are elongated at every cell cycle. This model also explains how telomere-binding proteins negatively regulate telomere length: They may provide a simple barrier, like the nucleosome, or some may actively promote dissociation of telomerase from the fork.

There are precedents for proteins traveling with the replication fork, including Mrc1 and Tof1, which form the fork progression complex (Katou et al. 2003). DDK travels with the replication fork to regulate double-strand breaks in meiosis (Murakami and Keeney 2014), and RRM3 travels with the fork to promote replication through specific barriers (Azvolinsky et al. 2006). The FACT complex, involved in chromatin remodeling, and Dia2, involved in replication termination, are also tethered to the replisome (Morohashi et al. 2009; Foltman et al. 2013).

There is early evidence from ciliates that telomerase also travels with the replication fork. In hypotrichous ciliates, replication initiation and progression are coordinated across the macronucleus in a "replication band" (Olins et al. 1989). This band progresses synchronously across the nucleus synthesizing DNA. The Cech laboratory (Fang and Cech 1995) showed that telomerase associates with these replication bands in Oxytricha as it travels with the replication forks during S phase. The coordination of replication fork progression and telomerase delivery to the very end would help explain why telomerase elongates telomeres only at the very end of S phase.

The relative stoichiometries of telomerase and replication forks may explain the stochastic nature of telomere elongation. The concentration of telomerase in vivo is very low; in $S$. cerevisiae, there are $\sim 20$ copies of telomerase per cell, and in human cancer cell lines, there are -250 copies of telomerase per cell (Mozdy and Cech 2006; Xi and Cech 2014). In S. cerevisiae, there are $\sim 626$ unique origins as well as $>200$ rDNA origins, a subset of which fires each cell cycle (Siow et al. 2012); thus, telomerase might associate with only a small fraction of the forks as they travel to the ends of chromosomes. As discussed below, telomerase may also have a higher probability of associat- ing with telomeric forks, since it binds to an alternative, telomere-specific RPA.

\section{Origin placement and firing efficiency could regulate telomere length}

The replication fork model provides a plausible explanation of two previously mystifying results: how subtelomeric sequences and the regulation of origin firing both affect telomere length. Both origin location and nonfiring of a telomeric origin will affect how far a fork must travel before it reaches the chromosome end (Fig. 2). The probability that telomerase will remain bound to the replication fork until it reaches the end of the chromosome will increase with a shorter distance between the most telomere-proximal origin and the chromosome end.

The differential locations of origins may explain a curious discovery in the Petes laboratory (Craven and Petes 1999) that the lengths of telomeres containing a $\mathrm{Y}^{\prime}$ subtelomeric sequence are regulated differently than telomeres containing a subtelomeric $\mathrm{X}$ sequence. Telomeres in $S$. cerevisiae contain two types of repetitive subtelomeric sequences (termed $\mathrm{X}$ or $\mathrm{Y}^{\prime}$ ) immediately adjacent to the G-rich telomere repeats (Chan and Tye 1983). Both of these elements contain replication origins, but the distance of the origin from the chromosome end varies in the two repeats (Louis 1995). The replication fork model of telomere length regulation would suggest that differential proximity to an origin in $\mathrm{X}$ - and $\mathrm{Y}^{\prime}$-containing telomeres could result in different probabilities of telomere elongation (Fig. 2).

\section{Replication origin firing regulates telomere length}

A second curious finding that can be explained by the replication fork model is the role of Rif1 in regulating origin firing and telomere length. Telomeric origins replicate late in S phase, often do not fire, and are passively replicated by forks from neighboring origins (McCarroll and Fangman 1988; Raghuraman et al. 2001). Strikingly, it is the telomeric location-not the DNA sequence of the origins-that determines their firing efficacy (Ferguson and Fangman 1992). If an early-firing origin from


Figure 2. Distance from an origin may affect telomere length. Telomere-proximal origins are inhibited from firing and can be passively replicated by adjacent origins. Here, Ori 1 is efficient, while Ori 2 does not fire in every cell cycle. If telomerase travels with the fork that initiates at Ori 1 , the probability of it reaching the end is relatively low. In contrast, if Ori 2 fires, there is a shorter distance to the chromosome end, and telomerase has a high probability of elongating that telomere. Rif1 normally blocks the telomeric Ori 2 from firing; in the absence of Rif1, Ori 2 will fire, and telomeres will elongate. 
elsewhere in the genome is relocated to the telomere, it will now fire late or not at all. Conversely, a telomeric origin placed on a circular plasmid will fire early and efficiently. Strikingly, this late replication of a telomeric origin is conserved in human cells (Smith and Higgs 1999|. New results directly link the telomere-binding protein Rif1 to this regulation of telomeric origin firing.

Rif1 was first identified in $S$. cerevisiae as a negative telomere length regulator and helped form the basis for the protein-counting model (Hardy et al. 1992; Marcand et al. 1997; Levy and Blackburn 2004). Experiments from several different groups now show that Rif1 is an evolutionarily conserved regulator of origin firing. Deletion of RIF1 in yeast or knockdown in mammalian cells allows the origins that were blocked in early $S$ phase to now fire (Buonomo et al. 2009; Lian et al. 2011; Cornacchia et al. 2012; Hayano et al. 2012; Yamazaki et al. 2012; Mattarocci et al. 2014; Peace et al. 2014; Sreesankar et al. 2015). Rif1 blocks the origin firing through recruitment of protein phosphatase 1 (PP1). PP1 antagonizes the action of the DDK1 kinase, which is required for origin firing (Dave et al. 2014; Hiraga et al. 2014; Mattarocci et al. 2014). Rif1 bound at telomere repeats will thus recruit PP1 and inhibit firing of origins near the telomere. Longer telomeres would presumably have more bound Rif1, which could increase PP1 recruitment and decrease firing of telomere-proximal origins.

The replication model suggests how increasing the probability of telomeric origin firing can lead to longer telomeres in a rif1 $\Delta$ deletion mutant. If the telomereproximal origin does not fire due to Rif1/PP1 activity, then replication origins will have to come from the next most internal origin (Fig. 2). However, when RIF1 is deleted, the telomere-proximal origins fire, thus decreasing the distance to the chromosome end and increasing the probability that telomerase will elongate the telomere. The replication fork model thus links the long telomeres in RIF1 deletion mutants with their effect on origin firing.

\section{A feedback loop for origin activation and repression may regulate telomere length}

Telomere length homeostasis may be established by a feedback loop between origin firing efficacy and telomere length (Fig. 3). The increased recruitment of PP1 to long telomeres decreases the probability of adjacent origin fir- ing, and thus, over many cell cycles, long telomeres will shorten due to the end replication problem. When that telomere becomes shorter, there will be less Rif1 bound, and the telomere-proximal origin can fire again, thus increasing the probability that telomerase will arrive at the end to extend that telomere. Interestingly, when a telomere is artificially shortened, the telomere-proximal origin fires more efficiently (Bianchi and Shore 2007a), supporting a feedback mechanism between telomere length, origin activity, and telomere elongation (Fig. 3). Having outlined the general concept of the replication fork model of telomere elongation, below I examine how previous experiments that connected replication and telomere length can be interpreted in light of this model.

\section{Telomere elongation is linked to replication}

The association of telomere length changes with DNA replication has been noted for some time, and, in fact, some elements of this model have been previously suggested in the literature. Wellinger et al. (1993) proposed that origin firing is coupled to telomere elongation and also that telomere elongation requires passage of a replication fork (Dionne and Wellinger 1998). Other groups have also linked origin firing to telomere elongation. By following elongation of an artificially shortened telomere in $S$. cerevisiae through the cell cycle, two groups found that telomere elongation by telomerase coincides exactly with telomere replication by the replisome (Marcand et al. 2000; Bianchi and Shore 2007a), and similar experiments show that this is the case in human cells as well (Hirai et al. 2012). Finally, chromatin immunoprecipitation experiments in S. cerevisiae; Schizosaccharomyces pombe, and human cells show that telomerase arrives at telomeres late in S phase. (Taggart et al. 2002; Smith et al. 2003; Bianchi and Shore 2007b; Moser et al. 2009; Hirai et al. 2012). These experiments are all consistent with the model in which telomerase arrives at the telomere with the replication fork. With a new framework for understanding the linkage of replication and telomere length, previous experimental results can be reinterpreted. For example, proteins that were proposed to "recruit" telomerase to the telomere 3 ' end ssDNA overhang, such as Cdc13 and Est1 (Evans and Lundblad 1999), instead may recruit telomerase to the ssDNA created at a telomeric replication fork.

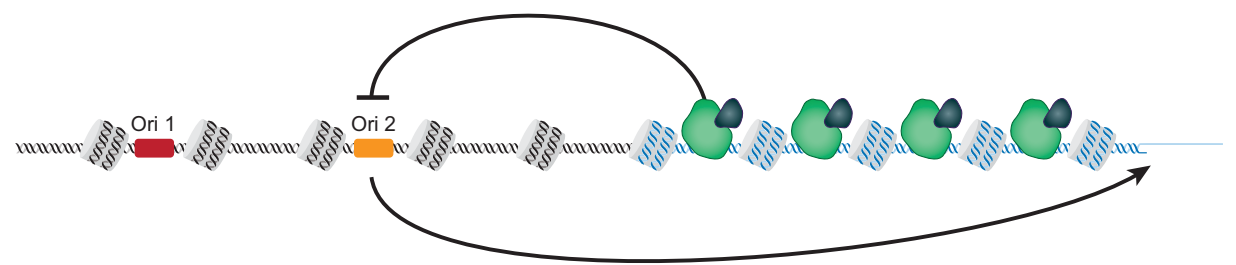

Figure 3. Feedback regulation of origin firing maintains telomere length homeostasis. At long telomeres, local Rif1 binding to telomere DNA (blue helix) blocks origin firing at proximal telomeres in adjacent DNA (black helix). The telomere is then replicated from the more distal Ori 1. At short telomeres, the fewer binding sites for Rifl allows Ori 2 firing and this increases the probability of telomere extension. 


\section{Lagging strand DNA polymerases and Okazaki fragment} processing are linked to telomere elongation

Over 30 years ago, telomere length was shown to be altered by mutations in components of lagging strand DNA synthesis (Carson and Hartwell 1985). Lagging strand replication occurs by synthesis of short stretches of DNA, called Okazaki fragments, followed by their maturation and ligation to generate a continuous DNA strand (Kurth and O'Donnell 2013). Each Okazaki fragment begins with the synthesis of a primer by the DNA polymerase $a /$ primase complex; PCNA is then loaded and recruits DNA polymerase $\delta$ (Langston et al. 2009; O'Donnell et al. 2013). During Okazaki fragment maturation, the nascent DNA/ RNA strand is processed by Fen 1 and Dna2 and joined to the upstream newly synthesized DNA (Balakrishnan and Bambara 2013). After ligation, PCNA must then be unloaded from the newly synthesized DNA (Kubota et al. 2013). Strikingly, mutations in many of the components of lagging strand synthesis affect telomere length.

In S. cerevisiae, specific hypomorphic alleles of POL1 (DNA polymerase $\alpha$ ) cause excessive telomere elongation and increased telomeric ssDNA (Carson and Hartwell 1985; Adams Martin et al. 2000). Mutations in genes encoding DNA primase (Pol12), Dna2, and Fen1 that process Okazaki fragments also increase ssDNA and telomere length (Parenteau and Wellinger 1999; Grossi et al. 2004; Budd et al. 2006). Also, mutations in PIF1, a helicase involved in Okazaki fragment maturation (Budd et al. 2006; Bochman et al. 2010), have long telomeres (Schulz and Zakian 1994). Mutations in genes encoding in the canonical replication factor C (RFC), which loads PCNA (Adams and Holm 1996), as well as in an alternative RFC (composed of Elg1, Ctf18, and Rad24), which unloads PCNA, cause significant telomere elongation (Kanellis et al. 2003; Kubota et al. 2015). This association of lagging strand replication components, including DNA polymerase $\alpha$, RFC, and Fen1, with telomere length is conserved across eukaryotes (Dahlen et al. 2003; Sampathi et al. 2009; Takashi et al. 2009; Derboven et al. 2014). The mechanism by which impairment of lagging strand synthesis might lead to telomere elongation is not clear and might seem counterintuitive. Perhaps components of the fork stabilization complex stabilize telomerase association with a stalled fork. While the mechanism is not clear, the mechanistic link between lagging strand synthesis and telomere length was further supported by Gottschling's group (Diede and Gottschling 1999). They found that DNA polymerases $\alpha$ and $\delta$ and DNA primase are each absolutely required for de novo telomere addition by telomerase (Diede and Gottschling 1999). Examining this link in the context of telomerase association with the fork might shed light on the mechanism of telomere length regulation.

\section{Telomere-specific RPA involved in telomere maintenance}

The identification of a telomere-specific RPA in yeast further strengthens the link between replication and telo- mere length. RPA is the eukaryotic ssDNA-binding protein that binds the ssDNA behind the helicase at the fork (Fairman and Stillman 1988; Wold and Kelly 1988). The RPA complex is a trimer containing RPA70, RPA32, and RPA14 that binds to ssDNA and is required for DNA replication (Erdile et al. 1990; Brill and Stillman 1991). Work from the Lundblad laboratory (Gao et al. 2007) first suggested that Cdc13 and its two binding partners, Stn1 and Ten1, form a trimeric complex protein resembling RPA. The similarity to RPA was confirmed by the crystal structure of several domains of Stn1 and Ten1 (Gelinas et al. 2009; Sun et al. 2009), indicating that Cdc13/Stn1/Ten1 form an alternative, telomere-specific RPA complex, termed t-RPA. This telomere-specific t-RPA (also called CST) is conserved across eukaryotes. In humans, Xenopus, and Arabidopsis, the large subunit CTC1 does not share sequence identity with CDC13, but they do have structural similarities (Miyake et al. 2009; Surovtseva et al. 2009; Price et al. 2010). Stn1 and Ten 1 are more conserved, and the crystal structure of the human STN1-TEN1 subcomplex shows structural conservation with the $S$. cerevisiae t-RPA (Bryan et al. 2013). Mutations in CTC1 cause telomere shortening in patients with human telomere syndromes (Anderson et al. 2012), and siRNA disruption of Stn1 and Ten1 increases telomere length in cultured cells (Bryan et al. 2013), highlighting the role of these proteins in mammalian length regulation.

The t-RPA interacts with polymerase a/primase (Nugent et al. 1996; Qi and Zakian 2000), as does the canonical RPA (Tsurimoto and Stillman 1989), once again linking lagging strand synthesis with telomere length regulation. A cocrystal shows binding of the Cdc13 N-terminal OB-fold domain to DNA polymerase a (Sun et al. 2011). Stn 1 and Ten 1 in human cells were first identified as DNA polymerase a/primase accessory proteins (Goulian et al. 1990), and biochemical reconstitution shows that the yeast t-RPA (CST) complex can stimulate DNA primase activity in vitro (Lue et al. 2014), providing functional evidence for a role in DNA replication as well as telomere length regulation.

\section{Conserved interaction of RPA and telomerase}

If Cdc13 is a part of an alternative RPA, how do we reconcile this with its proposed role in binding of the telomere G-strand overhang and providing end protection? The fact that Cdc13 is not needed for end protection outside of $S$ phase (Vodenicharov et al. 2010) and that chromatin immunoprecipitation (ChIP) experiments show that Cdc13 binds telomeres almost exclusively in S phase calls into question the model in which Cdc13 is constitutively bound to the telomeric G-strand overhang. Cdc13 (and the whole t-RPA complex) was proposed to associate with the single-stranded telomeric DNA at the replication fork (Gao et al. 2010), and experiments indicate that it does (Faure et al. 2010). Lundblad and colleagues (Gao et al. 2010) have proposed that t-RPA facilitates replication though telomeric DNA and prevents replication fork 
collapse. t-RPA binding to DNA polymerase a suggests that it is also directly linked to telomere lagging strand replication. If Cdc13 associates with single-stranded telomeric DNA just behind the fork, it would explain the finding that $\mathrm{Cdc13}$ is found at telomeres in late $S$ phase. Telomeres replicate late, and thus the single-stranded telomeric DNA would only be exposed on the lagging strand late in S phase. The association of Cdc13 with polymerase a put this alternative t-RPA squarely at the replication fork.

\section{Telomerase associates with t-RPA}

We have known for $>15$ years that CDC13 binds telomerase through interaction with Est1 (Evans and Lundblad 1999). The recent cryo-electron microscopy (cryo-EM) structure of the Tetrahymena telomerase holoenzyme also directly links telomerase to t-RPA. The structure shows that two distinct t-RPA complexes are bound with TERT in the telomerase holoenzyme (Jiang et al. 2015). These studies provide compelling evidence that telomerase may associate with the replication fork though its interaction with t-RPA, and thus this complex is one candidate for a factor that might mediate telomerase association with the replication fork, although other models for recruiting telomerase to the fork should also be considered.

As discussed above, in ciliates, telomerase travels with replication bands that represent synchronous replication forks. The telomere-binding protein $\mathrm{TBPa} / \mathrm{TBP} \beta$ from Oxytricha nova (Fang and Cech 1995) and Euplotes (Skopp et al. 1996) also travels with the fork, further suggesting that $\mathrm{TBP} \alpha / \mathrm{TBP} \beta$ may be part of a t-RPA that associates with telomerase.

\section{Conclusions}

The protein-counting model explains some of the experimental data on the negative regulation of telomere length but does not account for the role of origin firing or lagging strand synthesis in regulating length. When a model is drawn many times in articles and reviews, it influences how scientists interpret their experiments. Many aspects of this replication fork model still need to be tested. However, even if some aspects are not borne out, examining telomere regulation from a new angle may still inspire new interpretations of both past and future experiments. This model, I hope, will be refined or replaced as we learn more about how the cell maintains telomeres in an exquisite balance between lengthening and shortening.

\section{Acknowledgments}

I appreciate input and feedback that I have received from a number of people over the last year while developing and refining the ideas presented here. First, the Greider, Armanios, and Holland laboratories gave feedback at several group meetings, and the Molecular Biology and Genetics department faculty provided input at faculty chalk talks. I am indebted to several people in the rep- lication field, Steve Bell, James Berger, Thomas Kelly, and Bruce Stillman for talking over some of these issues and reading the manuscript, and I thank Victoria Lundblad and Jeremy Nathans for encouragement to publish this working model. I thank Cate Kiefe for extensive work on the figures. The Greider laboratory is supported by National Institutes of Health grants AG009383 and CA160300 and the Allegheny Health Network Cancer Research Fund.

\section{References}

Adams AK, Holm C. 1996. Specific DNA replication mutations affect telomere length in Saccharomyces cerevisiae. Mol Cell Biol 16: 4614-4620.

Adams Martin A, Dionne I, Wellinger RJ, Holm C. 2000. The function of DNA polymerase $\alpha$ at telomeric G tails is important for telomere homeostasis. Mol Cell Biol 20: 786796.

Anderson BH, Kasher PR, Mayer J, Szynkiewicz M, Jenkinson EM, Bhaskar SS, Urquhart JE, Daly SB, Dickerson JE, O'Sullivan J, et al. 2012. Mutations in CTC1, encoding conserved telomere maintenance component 1 , cause Coats plus. Nat Genet 44: 338-342.

Armanios M. 2009. Syndromes of telomere shortening. Annu Rev Genomics Hum Genet 10: 45-61.

Azvolinsky A, Dunaway S, Torres JZ, Bessler JB, Zakian VA. 2006. The $S$. cerevisiae Rrm3p DNA helicase moves with the replication fork and affects replication of all yeast chromosomes. Genes Dev 20: 3104-3116.

Balakrishnan L, Bambara RA. 2013. Okazaki fragment metabolism. Cold Spring Harb Perspect Biol 5: a010173.

Ballew BJ, Lundblad V. 2013. Multiple genetic pathways regulate replicative senescence in telomerase-deficient yeast. Aging Cell 12: 719-727.

Bianchi A, Shore D. 2007a. Early replication of short telomeres in budding yeast. Cell 128: 1051-1062.

Bianchi A, Shore D. 2007b. Increased association of telomerase with short telomeres in yeast. Genes Dev 21: 1726-1730.

Bochman ML, Sabouri N, Zakian VA. 2010. Unwinding the functions of the Pifl family helicases. DNA Repair (Amst) 9: 237-249.

Brill SJ, Stillman B. 1991. Replication factor-A from Saccharomyces cerevisiae is encoded by three essential genes coordinately expressed at S phase. Genes Dev 5: 1589-1600.

Bryan C, Rice C, Harkisheimer M, Schultz DC, Skordalakes E. 2013. Structure of the human telomeric Stn1-Ten1 capping complex. PLoS One 8: e66756.

Budd ME, Reis CC, Smith S, Myung K, Campbell JL. 2006. Evidence suggesting that Pif1 helicase functions in DNA replication with the Dna2 helicase/nuclease and DNA polymerase $\delta$. Mol Cell Biol 26: 2490-2500.

Buonomo SB, Wu Y, Ferguson D, de Lange T. 2009. Mammalian Rif1 contributes to replication stress survival and homologydirected repair. J Cell Biol 187: 385-398.

Carson MJ, Hartwell L. 1985. CDC17: an essential gene that prevents telomere elongation in yeast. Cell 42: 249-257.

Chan CSM, Tye B. 1983. Organization of DNA sequences and replication origins at yeast telomeres. Cell 33: 563-573.

Chang M, Rothstein R. 2011. Rif1/2 and Tel1 function in separate pathways during replicative senescence. Cell Cycle 10: 3798-3799.

Cornacchia D, Dileep V, Quivy JP, Foti R, Tili F, SantarellaMellwig R, Antony C, Almouzni G, Gilbert DM, Buonomo SB. 2012. Mouse Rif1 is a key regulator of the replication- 
timing programme in mammalian cells. Embo $I$ 31: 3678-3690.

Craven RJ, Petes TD. 1999. Dependence of the regulation of telomere length on the type of subtelomeric repeat in the yeast Saccharomyces cerevisiae. Genetics 152: 1531-1541.

Dahlen M, Sunnerhagen P, Wang TS. 2003. Replication proteins influence the maintenance of telomere length and telomerase protein stability. Mol Cell Biol 23: 3031-3042.

Dave A, Cooley C, Garg M, Bianchi A. 2014. Protein phosphatase 1 recruitment by Rif1 regulates DNA replication origin firing by counteracting DDK activity. Cell Rep 7: 53-61.

Derboven E, Ekker H, Kusenda B, Bulankova P, Riha K. 2014. Role of STN1 and DNA polymerase $\alpha$ in telomere stability and genome-wide replication in Arabidopsis. PLoS Genet 10: e1004682.

Diede SJ, Gottschling DE. 1999. Telomerase-mediated telomere addition in vivo requires DNA primase and DNA polymerases $\alpha$ and $\delta$. Cell 99: 723-733.

Dionne I, Wellinger RJ. 1998. Processing of telomeric DNA ends requires the passage of a replication fork. Nucleic Acids Res 26: $5365-5371$.

Erdile LF, Wold MS, Kelly TJ. 1990. The primary structure of the 32-kDa subunit of human replication protein A. J Biol Chem 265: 3177-3182.

Evans SK, Lundblad V. 1999. Est1 and Cdc13 as comediators of telomerase access. Science 286: 117-120.

Fairman MP, Stillman B. 1988. Cellular Factors required for multiple stages of SV40 DNA replication. EMBO J 7: 1211-1218.

Fang G, Cech TR. 1995. Telomerase RNA localized in the replication band and spherical subnuclear organelles in hypotrichous ciliates. J Cell Biol 130: 243-253.

Faure V, Coulon S, Hardy J, Geli V. 2010. Cdc13 and telomerase bind through different mechanisms at the lagging- and leading-strand telomeres. Mol Cell 38: 842-852.

Ferguson BM, Fangman WL. 1992. A position effect on the time of replication origin activation in yeast. Cell 68: 333-339.

Foltman M, Evrin C, De Piccoli G, Jones RC, Edmondson RD, Katou Y, Nakato R, Shirahige K, Labib K. 2013. Eukaryotic replisome components cooperate to process histones during chromosome replication. Cell Rep 3: 892-904.

Gao H, Cervantes RB, Mandell EK, Otero JH, Lundblad V. 2007. RPA-like proteins mediate yeast telomere function. Nat Struct Mol Biol 14: 208-214.

Gao H, Toro TB, Paschini M, Braunstein-Ballew B, Cervantes RB, Lundblad V. 2010. Telomerase recruitment in Saccharomyces cerevisiae is not dependent on Tell-mediated phosphorylation of Cdc13. Genetics 186: 1147-1159.

Gelinas AD, Paschini M, Reyes FE, Heroux A, Batey RT, Lundblad V, Wuttke DS. 2009. Telomere capping proteins are structurally related to RPA with an additional telomere-specific domain. Proc Natl Acad Sci 106: 19298-19303.

Goulian M, Heard CJ, Grimm SL. 1990. Purification and properties of an accessory protein for DNA polymerase a/primase. I Biol Chem 265: 13221-13230.

Grandin N, Reed SI, Charbonneau M. 1997. Stn1, a new Saccharomyces cerevisiae protein, is implicated in telomere size regulation in association with Cdc13. Genes Dev 11: 512-527.

Grandin N, Damon C, Charbonneau M. 2001. Ten1 functions in telomere end protection and length regulation in association with Stn1 and Cdc13. Embo J 20: 1173-1183.

Greider CW. 1999. Telomerase activation: one step on the road to cancer? Trends Genet 15: 109-112.

Greider CW, Blackburn EH. 1985. Identification of a specific telomere terminal transferase activity in Tetrahymena extracts. Cell 43: 405-413.
Griffith JD, Comeau L, Rosenfield S, Stansel RM, Bianchi A, Moss $\mathrm{H}$, de Lange T. 1999. Mammalian telomeres end in a large duplex loop. Cell 97: 503-514.

Grossi S, Puglisi A, Dmitriev PV, Lopes M, Shore D. 2004. Pol12, the B subunit of DNA polymerase $\alpha$, functions in both telomere capping and length regulation. Genes Dev 18: 992-1006.

Grunstein M. 1997. Molecular model for telomeric heterochromatin in yeast. Curr Opin Cell Biol 9: 383-387.

Hardy CF, Sussel L, Shore D. 1992. A RAP1-interacting protein involved in transcriptional silencing and telomere length regulation. Genes Dev 6: 801-814.

Hayano M, Kanoh Y, Matsumoto S, Renard-Guillet C, Shirahige K, Masai H. 2012. Rif1 is a global regulator of timing of replication origin firing in fission yeast. Genes Dev 26: 137-150.

Hiraga S, Alvino GM, Chang F, Lian HY, Sridhar A, Kubota T, Brewer BJ, Weinreich M, Raghuraman MK, Donaldson AD. 2014. Rif1 controls DNA replication by directing protein phosphatase 1 to reverse Cdc7-mediated phosphorylation of the MCM complex. Genes Dev 28: 372-383.

Hirai Y, Masutomi K, Ishikawa F. 2012. Kinetics of DNA replication and telomerase reaction at a single-seeded telomere in human cells. Genes Cells 17: 186-204.

Hockemeyer D, Palm W, Wang RC, Couto SS, de Lange T. 2008. Engineered telomere degradation models dyskeratosis congenita. Genes Dev 22: 1773-1785.

Jiang J, Chan H, Cash DD, Miracco EJ, Ogorzalek Loo RR, Upton HE, Cascio D, O’Brien Johnson R, Collins K, Loo JA, et al. 2015. Structure of Tetrahymena telomerase reveals previously unknown subunits, functions, and interactions. Science 350: aab4070.

Kanellis P, Agyei R, Durocher D. 2003. Elg1 forms an alternative PCNA-interacting RFC complex required to maintain genome stability. Curr Biol 13: 1583-1595.

Katou Y, Kanoh Y, Bando M, Noguchi H, Tanaka H, Ashikari T, Sugimoto K, Shirahige K. 2003. S-phase checkpoint proteins Tof 1 and Mrcl form a stable replication-pausing complex. $\mathrm{Na}$ ture 424: 1078-1083.

Kubota T, Myung K, Donaldson AD. 2013. Is PCNA unloading the central function of the Elg1/ATAD5 replication factor C-like complex? Cell Cycle 12: 2570-2579.

Kubota T, Katou Y, Nakato R, Shirahige K, Donaldson AD. 2015. Replication-coupled PCNA unloading by the Elg1 complex occurs genome-wide and requires okazaki fragment ligation. Cell Rep 12: 774-787.

Kurth I, O'Donnell M. 2013. New insights into replisome fluidity during chromosome replication. Trends Biochem Sci 38: 195-203.

Langston LD, Indiani C, O'Donnell M. 2009. Whither the replisome: emerging perspectives on the dynamic nature of the DNA replication machinery. Cell Cycle 8: 2686-2691.

Levy DL, Blackburn EH. 2004. Counting of Riflp and Rif2p on Saccharomyces cerevisiae telomeres regulates telomere length. Mol Cell Biol 24: 10857-10867.

Lian HY, Robertson ED, Hiraga S, Alvino GM, Collingwood D, McCune HJ, Sridhar A, Brewer BJ, Raghuraman MK, Donaldson $\mathrm{AD}$. 2011. The effect of $\mathrm{Ku}$ on telomere replication time is mediated by telomere length but is independent of histone tail acetylation. Mol Biol Cell 22: 1753-1765.

Lin JJ, Zakian VA. 1996. The Saccharomyces CDC13 protein is a single-strand TG1-3 telomeric DNA-binding protein in vitro that affects telomere behavior in vivo. Proc Natl Acad Sci 93: $13760-13765$.

Loayza D, de Lange T. 2003. POT1 as a terminal transducer of TRF1 telomere length control. Nature 423: 1013-1018. 
Louis EJ. 1995. The chromosome ends of Saccharomyces cerevisiae. Yeast 11: 1553-1573.

Lue NF, Chan J, Wright WE, Hurwitz J. 2014. The CDC13-STN1TEN1 complex stimulates Pol $\alpha$ activity by promoting RNA priming and primase-to-polymerase switch. Nat Commun 5: 5762.

Marcand S, Gilson E, Shore D. 1997. A protein-counting mechanism for telomere length regulation in yeast. Science 275: 986-990.

Marcand S, Brevet V, Gilson E. 1999. Progressive cis-inhibition of telomerase upon telomere elongation. Embo / 18: 3509-3519.

Marcand S, Brevet V, Mann C, Gilson E. 2000. Cell cycle restriction of telomere elongation. Curr Biol 10: 487-490.

Mattarocci S, Shyian M, Lemmens L, Damay P, Altintas DM, Shi T, Bartholomew CR, Thoma NH, Hardy CF, Shore D. 2014. Rif1 controls DNA replication timing in yeast through the PP1 phosphatase Glc7. Cell Rep 7: 62-69.

McCarroll RM, Fangman WL. 1988. Time of replication of yeast centromeres and telomeres. Cell 54: 505-513.

Miyake Y, Nakamura M, Nabetani A, Shimamura S, Tamura M, Yonehara S, Saito M, Ishikawa F. 2009. RPA-like mammalian Ctc1-Stn1-Ten1 complex binds to single-stranded DNA and protects telomeres independently of the Potl pathway. Mol Cell 36: 193-206.

Morohashi H, Maculins T, Labib K. 2009. The amino-terminal TPR domain of Dia2 tethers SCF(Dia2) to the replisome progression complex. Curr Biol 19: 1943-1949.

Moser BA, Subramanian L, Khair L, Chang YT, Nakamura TM. 2009. Fission yeast Tel1(ATM) and Rad3(ATR) promote telomere protection and telomerase recruitment. PLoS Genet 5: e1000622.

Mozdy AD, Cech TR. 2006. Low abundance of telomerase in yeast: implications for telomerase haploinsufficiency. RNA 12: $1721-1737$.

Murakami H, Keeney S. 2014. DDK links replication and recombination in meiosis. Cell Cycle 13: 3621-3622.

Nugent CI, Hughes TR, Lue NF, Lundblad V. 1996. Cdc13p: a single-strand telomeric DNA-binding protein with a dual role in yeast telomere maintenance. Science 274: 249-252.

O’Donnell M, Langston L, Stillman B. 2013. Principles and concepts of DNA replication in bacteria, archaea, and eukarya. Cold Spring Harb Perspect Biol 5: a010108.

Olins DE, Olins AL, Cacheiro LH, Tan EM. 1989. Proliferating cell nuclear antigen/cyclin in the ciliate Euplotes eurystomus: localization in the replication band and in micronuclei. J Cell Biol 109: 1399-1410.

Palm W, de Lange T. 2008. How shelterin protects mammalian telomeres. Annu Rev Genet 42: 301-334.

Parenteau J, Wellinger RJ. 1999. Accumulation of single-stranded DNA and destabilization of telomeric repeats in yeast mutant strains carrying a deletion of RAD27. Mol Cell Biol 19: 4143-4152.

Peace JM, Ter-Zakarian A, Aparicio OM. 2014. Rif1 regulates initiation timing of late replication origins throughout the $S$. cerevisiae genome. PLoS One 9: e98501.

Pisano S, Galati A, Cacchione S. 2008. Telomeric nucleosomes: forgotten players at chromosome ends. Cell Mol Life Sci 65: 3553-3563.

Price CM, Boltz KA, Chaiken MF, Stewart JA, Beilstein MA, Shippen DE. 2010. Evolution of CST function in telomere maintenance. Cell Cycle 9: 3157-3165.

Qi H, Zakian VA. 2000. The Saccharomyces telomere-binding protein Cdc13p interacts with both the catalytic subunit of DNA polymerase $\alpha$ and the telomerase-associated Est1 protein. Genes Dev 14: 1777-1788.
Raghuraman MK, Winzeler EA, Collingwood D, Hunt S, Wodicka L, Conway A, Lockhart DJ, Davis RW, Brewer BJ, Fangman WL. 2001. Replication dynamics of the yeast genome. Science 294: $115-121$.

Rossetti L, Cacchione S, De Menna A, Chapman L, Rhodes D, Savino M. 2001. Specific interactions of the telomeric protein Raplp with nucleosomal binding sites. I Mol Biol 306: 903-913.

Sampathi S, Bhusari A, Shen B, Chai W. 2009. Human flap endonuclease $\mathrm{I}$ is in complex with telomerase and is required for telomerase-mediated telomere maintenance. I Biol Chem 284: 3682-3690.

Schulz VP, Zakian VA. 1994. The Saccharomyces PIF1 DNA helicase inhibits telomere elongation and de novo telomere formation. Cell 76: 145-155.

Shore D, Bianchi A. 2009. Telomere length regulation: coupling DNA end processing to feedback regulation of telomerase. EMBO I 28: 2309-2322.

Siow CC, Nieduszynska SR, Muller CA, Nieduszynski CA. 2012. OriDB, the DNA replication origin database updated and extended. Nucleic Acids Res 40: D682-D686.

Skopp R, Wang W, Price C. 1996. rTP: a candidate telomere protein that is associated with DNA replication. Chromosoma 105: 82-91.

Smith ZE, Higgs DR. 1999. The pattern of replication at a human telomeric region (16p13.3): its relationship to chromosome structure and gene expression. Hum Mol Genet 8: 1373-1386.

Smith CD, Smith DL, DeRisi JL, Blackburn EH. 2003. Telomeric protein distributions and remodeling through the cell cycle in Saccharomyces cerevisiae. Mol Biol Cell 14: 556-570.

Smogorzewska A, van Steensel B, Bianchi A, Oelmann S, Schaefer MR, Schnapp G, de Lange T. 2000. Control of human telomere length by TRF1 and TRF2. Mol Cell Biol 20: 1659-1668.

Sreesankar E, Bharathi V, Mishra RK, Mishra K. 2015. Drosophila Rif1 is an essential gene and controls late developmental events by direct interaction with PP1-87B. Sci Rep 5: 10679.

Sun J, Yu EY, Yang Y, Confer LA, Sun SH, Wan K, Lue NF, Lei M. 2009. Stn1-Ten1 is an Rpa2-Rpa3-like complex at telomeres. Genes Dev 23: 2900-2914.

Sun J, Yang Y, Wan K, Mao N, Yu TY, Lin YC, DeZwaan DC, Freeman BC, Lin JJ, Lue NF, et al. 2011. Structural bases of dimerization of yeast telomere protein $\mathrm{Cdc} 13$ and its interaction with the catalytic subunit of DNA polymerase a. Cell Res 21: 258-274.

Surovtseva YV, Churikov D, Boltz KA, Song X, Lamb JC, Warrington R, Leehy K, Heacock M, Price CM, Shippen DE. 2009. Conserved telomere maintenance component 1 interacts with STN1 and maintains chromosome ends in higher eukaryotes. Mol Cell 36: 207-218.

Sussel L, Shore D. 1991. Separation of transcriptional activation and silencing functions of the RAP1-encoded repressor/activator protein 1: isolation of viable mutants affecting both silencing and telomere length. Proc Natl Acad Sci 88: 7749-7753.

Taggart AK, Teng SC, Zakian VA. 2002. Estlp as a cell cycle-regulated activator of telomere-bound telomerase. Science 297: 1023-1026.

Takai KK, Hooper S, Blackwood S, Gandhi R, de Lange T. 2010. In vivo stoichiometry of shelterin components. J Biol Chem 285: 1457-1467.

Takashi Y, Kobayashi Y, Tanaka K, Tamura K. 2009. Arabidopsis replication protein A 70a is required for DNA damage response and telomere length homeostasis. Plant Cell Physiol 50: 1965-1976. 
Teixeira MT, Arneric M, Sperisen P, Lingner J. 2004. Telomere length homeostasis is achieved via a switch between telomerase-extendible and -nonextendible states. Cell 117: 323-335.

Tommerup H, Dousmanis A, de Lange T. 1994. Unusual chromatin in human telomeres. Mol Cell Biol 14: 5777-5785.

Tsurimoto T, Stillman B. 1989. Multiple replication factors augment DNA synthesis by the two eukaryotic DNA polymeras-

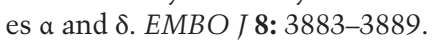

van Steensel B, de Lange T. 1997. Control of telomere length by the human telomeric protein TRF1. Nature 385: 740-743.

Vodenicharov MD, Laterreur N, Wellinger RJ. 2010. Telomere capping in non-dividing yeast cells requires Yku and Rap1. EMBO J 29: 3007-3019.

Wellinger RJ, Zakian VA. 2012. Everything you ever wanted to know about Saccharomyces cerevisiae telomeres: beginning to end. Genetics 191: 1073-1105.

Wellinger RJ, Wolf AJ, Zakian VA. 1993. Origin activation and formation of single-strand TG1-3 tails occur sequentially in late $\mathrm{S}$ phase on a yeast linear plasmid. Mol Cell Biol 13: 4057-4065.
Wold MS, Kelly T. 1988. Purification and characterization of replication protein A, a cellular protein required for in vitro replication of simian virus 40 DNA. Proc Natl Acad Sci 85: 2523-2527.

Wotton D, Shore D. 1997. A novel Raplp-interacting factor, Rif2p, cooperates with Rif1p to regulate telomere length in Saccharomyces cerevisiae. Genes Dev 11: 748-760.

Wright JH, Gottschling DE, Zakian VA. 1992. Saccharomyces telomeres assume a non-nucleosomal chromatin structure. Genes Dev 6: 197-210.

Xi L, Cech TR. 2014. Inventory of telomerase components in human cells reveals multiple subpopulations of hTR and hTERT. Nucleic Acids Res 42: 8565-8577.

Yamazaki S, Ishii A, Kanoh Y, Oda M, Nishito Y, Masai H. 2012. Rif1 regulates the replication timing domains on the human genome. EMBO J 31: 3667-3677.

Ye JZ, de Lange T. 2004. TIN2 is a tankyrase 1 PARP modulator in the TRF1 telomere length control complex. Nat Genet 36: 618-623. 


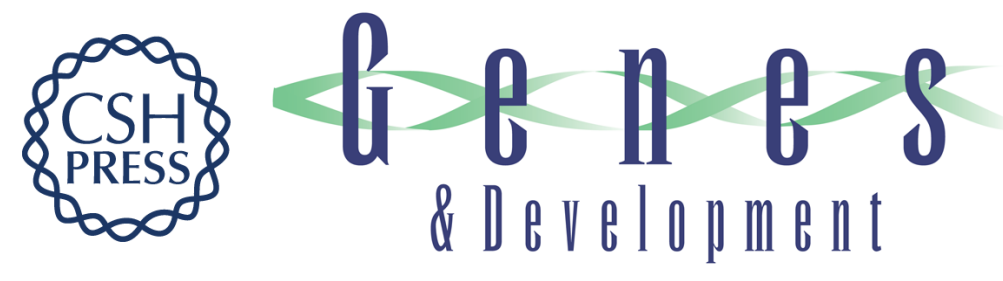

\title{
Regulating telomere length from the inside out: the replication fork model
}

\author{
Carol W. Greider
}

Genes Dev. 2016, 30:

Access the most recent version at doi:10.1101/gad.280578.116

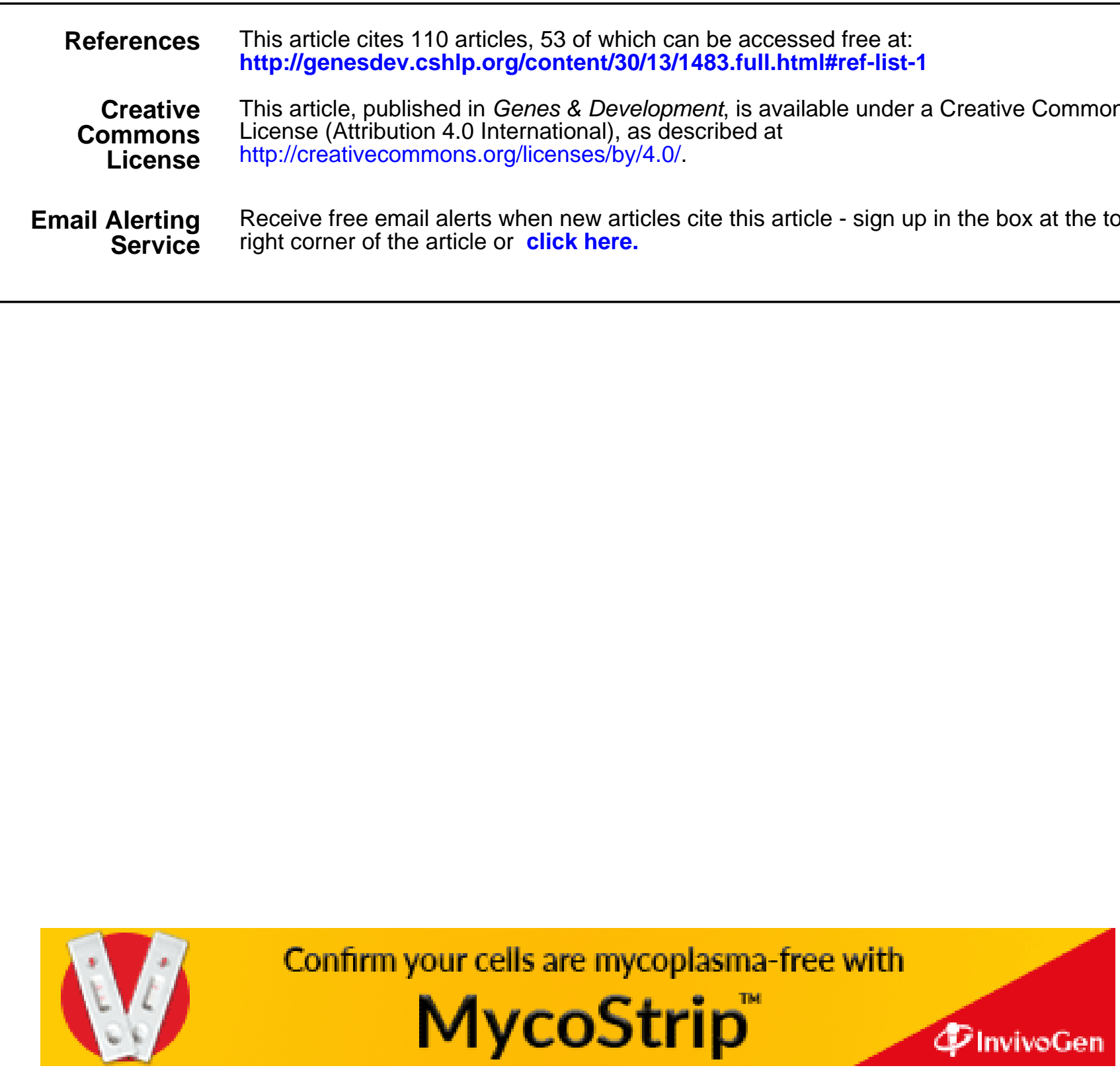

